\title{
Covid-19 Pandemic Influence on Consumer Buying Behaviour
}

\author{
Tina Vukasović \\ International School for Social and Business Studies, Celje, Slovenia \\ tina.vukasovic@mfdps.si
}

Purpose: The paper aims to present the connections between buying factors and their effects on consumer decision-making during the Covid-19 pandemic. The Covid-19 pandemic has upended all areas of life. We have all had to adapt to the so-called "new normality", which is, of course, neither easy nor desirable in any element of our lives.

Study design/methodology/approach: A quantitative survey was designed and conducted. The primary data were collected through a structured questionnaire. The survey was conducted by distributing questionnaires via e-mail. The distribution of the questionnaires was initiated according to the snowball principle in all Slovenian regions. The target population of the survey was the population of Slovenian citizens between 18 and 65 years of age.

Findings: Based on the data analysis, we find that the purchasing frequency decreased during the pandemic. A critical increase is observed in the use of online stores, namely online shopping. Consumer buying habits were most negatively affected by restrictive government decrees, which limited movement to municipalities, lower-income, resulting from partial closure of the economy and temporary lay-offs, and uncertainty regarding future employment. As evident from the research, the epidemic has caused significant changes in consumer buying habits.

Originality/value: The research results contributed findings of consumers' behavior and opinion during a state of emergency, contributing to further decision-making concerning sales and related procurement.

Keywords: Covid-19, consumers, decision-making, consumer behaviour

\section{Introduction}

On March 11th, 2020, the World Health Organization (WHO, 2020) declared the pandemic of highly transmissible coronavirus disease Covid-19, signalling its global spread. Since then, the rapid worldwide outbreak of the new coronavirus has triggered an alarming global health crisis. Governments of several countries have taken measures that dramatically affect the daily life of society. To slow down the transmission and spread of the coronavirus, the public health tactics of "social distancing" have been widely applied. Regions and even countries have been entirely locked down (ranging from contact limitations to total curfews); schools, universities, sports, and public facilities shut down; public events (including sports matches, concerts, and even marriages) are currently still prohibited in most countries. These measures not only affect the daily life of the population but have also led to significant economic consequences in economies around the world (Kraus et al., 2020).

Governments have set severe restrictions on companies in various industries, mandated social distancing and health protection policies (del Rio-Chanona et al., 2020). Although, as a result, demand in sectors such as healthcare has skyrocketed, demand in industries such as hospitality, air transportation, and tourism has evaporated (Kraus et al., 2020).

The Covid-19 pandemic has upended all areas of life. Health care measures taken to limit social contacts require personal and social responsibility from the consumer. By shopping in stores, the consumer is exposed to many social connections, so disregarding or inconsistently following the measures taken, his own health, the health of his loved ones, and the health of society as a whole are endangered. 
This paper aims to present trends in consumer behaviour when buying everyday products, also called fast-moving consumer goods (FMCG), regardless of the fluctuations during the Covid19 pandemic.

The Covid-19 pandemic has fundamentally changed the world as we know it. People are living differently, buying differently, and in many ways, thinking differently. As a result, consumers across the globe are looking at products and brands through a new lens.

\section{Consumer buying behaviour and purchasing factors}

The understanding of consumer behaviour extends to various arms of science and is a key to successful marketing. Consumer behaviour is defined as a behaviour consumers demonstrate while searching for, buying, using, disposing of, and evaluating products, services, and ideas expected to satisfy their needs (Schiffman and Kanuk, 2015). The process of buying decision making is defined as a comprehensive process of consumer decision making that occurs primarily in five, and occasionally, in seven consecutive levels (Peter and Olson 2005, 156; Solomon et al. 2006, 258). The process includes all parameters a consumer may encounter while buying products for the first time, experiencing a high level of purchase commitment. We talk about an expanded process of purchase decision making that consists of five or seven levels: problem/need identification, data and information collecting, evaluation of alternatives, consumer choice, and post-purchase behaviour/result; regarding the seven-level model, the use of purchased alternative (satisfaction or dissatisfaction with the purchased product) and disposal of unused products and their parts are added.

Consumerism is an active movement in today's society. Trends, such as globalization, specialization, and increasing competition, change together with the consumer's role. A consumer is no longer a mere classical buyer and product consumer but turns into an active participant in product designing, development, and supply (Wang, Lo and Yang, 2004, 171). Companies should, therefore, have better knowledge of consumers than in the past. They should be familiar with the factors influencing their buying decision-making. Consumer behaviour is, during the process of buying decision-making, affected by various factors. These can be divided into several factor (influence) groups: psychological (motivation, attitude, learning, and memory), social (reference groups, family, individual's role and position, status), personal (age and level of a family's life cycle, occupation, and financial situation, lifestyle, personality and self-image, values and beliefs), cultural (culture, social class), economic (price-monetary in non-monetary aspect, income, quality), individual differences and environmental impacts (Blackwell, Miniard, \& Engel, 2006; Bennett, 2011; Kotler \& Armstrong, 2018; Vukasović, 2020).

\section{Consumer behaviour in the time of the Covid-19 pandemic}

Consumer behaviour in a pandemic is determined by two factors, which may even be contradictory or unequal. On the one hand, there is a personal and social responsibility for one's own health, health of the loved ones, and health of the society as a whole, and on the other hand, there are the needs, habits, or even bad habits of consumers. In addition to these two factors, fear that stems from consumers' need for safety are present. Behavioural patterns vary depending on consumer diversity; therefore, it is interesting to have their actual opinions and identify various factors that influence their behavior during a pandemic (Vukasović and Jagodič, 2021).

Due to the state of emergency in the country, the terms and conditions of purchase have changed almost overnight. Shopping in shops has become very unusual. Some consumers could change their shopping habits as soon as the measures were taken and coped well with further tightening, while others had to adapt to personal changes. Sellers have also been faced with various urgent measures to ensure the highest possible level of safety for consumers at the time of purchase. 
Queues of people keeping safety distance were waiting in front of the stores, operating hours were shortened, some stores with non-essential goods had to close their doors, and certain retailers faced problems with stocks and distribution (Vukasović and Jagodič, 2021).

The Covid-19 pandemic has and will continue to affect almost all parts of society and the economy. The Statistical Office of the Republic of Slovenia has prepared an analysis of the situation in the country, which shall leave its mark on Slovenia in individual segments (Svetin, 2020):

- population: increased by 15,000 on January 1 st, 2020 , compared to 2019 , with more men in terms of gender, due to higher immigration from abroad with significantly more men than women among immigrants, while natural growth being negative, the population of Slovenia is ageing, the average age in 2019 was 43.4, we already have 252 centenarians;

- economy: in May 2020, annual deflation was $1.2 \%$, we recorded the most significant monthly decline in petrol and diesel prices in this millennium, in the first quarter of 2020, GDP was 2.3\% lower than in the same period in 2019, the decline in GDP was mainly due to the decrease in domestic sector demand, while foreign demand also declined;

- export and import: we recorded significantly lower trade in goods in both export and import, this applies to trade with EU members;

- labour market: was in good condition in the 1st quarter of 2020 , the impact of the pandemic has not yet been demonstrated;

- salaries: gross salaries for April 2020 were higher than gross salaries for March, increase in salaries was due to measures taken associated with the Covid-19 pandemic, and temporary laid-off workers reduced the number of employees receiving salaries borne by the employer;

- tourism: the pandemic paralyzed it completely, overnight stays in April were 99\% less than in April 2019, the guests who came were not tourists but persons who came to Slovenia as part of international study exchanges and stayed in our country for a longer time;

- economic climate: the mood in the economy and among the population is reflected in reduced confidence in all sectors of the economy and among consumers;

- food: the importance of home-grown food increased more than ever during the Covid-19 pandemic; in $2019,44 \%$ of all vegetables and $44 \%$ of all fresh fruit consumed was grown in agricultural areas, and $81 \%$ of the quantity of all meat consumed.

With the introduction of quarantine, extraordinary circumstances have also occurred in the market to sell goods and services. In retail stores with food and other everyday necessities, a special regime of hygienic measures was introduced overnight, as well as some organisational changes in the operation of stores, which:

- prohibits entry into the store in the case of infectious disease, with increased body temperature, and viral and bacterial infections;

- in all public enclosed spaces, makes it obligatory to use a protective mask or scarf or shawl to cover one's nose and mouth, in some instances also protective gloves;

- recommends regular disinfection, before entering and leaving the store, of hands, shopping carts, and baskets, and other items handed over to the consumer;

- also recommends frequent ventilation of service spaces;

- specifies a safety distance of at least $1.5 \mathrm{~m}$ in queues;

- limits the number of consumers in stores so that at least $20 \mathrm{~m}^{2}$ of space is provided for each visitor, purchases can be made by only one member of the household, without children;

- shortens the opening hours of stores until $6 \mathrm{pm}$; 
- sets the shopping time for vulnerable groups (e.g., the elderly, pregnant women, the disabled) between 8 am and 10 am and one hour before the store closes, the verification of the identity of customers is necessary;

- closes shops on Sundays and public holidays;

- recommends contactless payment methods with payment cards and advises against cash payments;

- recommends that we use alternative shopping methods such as online sales and delivery in a secure manner whereby the delivery person delivers the package in front of the front door and does not enter our home.

During the Covid-19 epidemic, in the field of digitalisation, online commerce experienced the peak of success. Customers have realised the value of simple shopping where they are not necessarily deprived of product quality. Covid -19 has changed trade and consumer behaviour. Consumers have changed the way they shop and their priorities in the products they buy. Visits to stores decreased by $3.3 \%$, e-commerce sales increased by $50 \%$ compared to 2019 , demand for luxury goods fell sharply, and demand for building materials also decreased. Food and everyday necessities are bought online, and health products, which previously have not been purchased online in such quantities.

The question is how different consumer behaviour will remain and for how long? Some of the changes will be profound and lasting, from how we will live our daily lives to how we will shop if we are a consumer and how we will sell if we are a retailer. Retailers need to be prepared for rapid changes in the organisation of trade and the conduct of trade activities.

Since its onset, the Covid-19 pandemic has spread to almost all countries of the world. Social and physical distancing measures, lockdowns of businesses, schools, and overall social life, which have become commonplace to curtail the spread of the disease, have also disrupted many regular aspects of life.

\section{Consequences of the COVID-19 pandemic for the economy}

The consequences of the pandemic affect human health and mortality, and the growth of the world economy. Because of this new impact, experts predict two possible scenarios. After the first, we can expect a significant decline in consumption, which is vital for the entire economic process. As a result, companies will start losing income and will be forced to lay off employees. The unemployment rate will rise sharply, and purchasing power will fall sharply, leading to a severe financial crisis. Business investment will decline, the pressure on the financial system will increase in proportion to the growing number of bankrupt companies.

Given that the virus is not just a seasonal disease, we are more likely to be hit by another scenario that may be fatal to the economy. Demand will be lower throughout the year, with the number of redundancies and bankruptcies in the most affected sectors of the economy rising by the end of 2020 and continuing in 2021. This could lead to an even greater financial crisis affecting SMEs and more pronounced in less developed economies. The consequences will affect the economy globally; all economic superpowers will face a decline in GDP. At best, the start of the recovery can be expected only in the second quarter of 2021.

In the Slovenian economy, especially in tourism, catering, trade, and manufacturing, the consequences of the pandemic are most noticeable. The Slovenian government wants to manage the situation in the country by reducing the long-term harmful effects on the economy and the population. To this end, it has developed strategic guidelines and adopted intervention measures to help the economy and the people. The state budget will be heavily burdened with targeted measures to maintain the functioning of companies and jobs, improve the social situation of people, and extraordinary assistance to the self-employed, agriculture, and scientific research 
projects to combat the epidemic and all other forms of aid. Rapid financial assistance to the population to prevent and mitigate the consequences of the epidemic, favourable loans, adjusted methods of paying taxes, deferred payment of contributions for the self-employed for the duration of quarantine are just some of the gifts of high government borrowing.

The negative economic growth, which we see by the decline in the country's total GDP (two quarters in a row compared to the same period last year), tells us that a recession has occurred. We had known its adverse effects since 2008 and 2009 when they led to a slowdown in the entire economy. The chain of economic consequences could be observed in production, the unemployment rate, the level of revenues, and reduced trade activity. While the recession does not have the same impact on all entities, its global consequences are very harmful or even devastating. In a recession, a company's sales revenue declines. The lower purchasing power of individuals and companies leads to a reduced volume of trade activity. In other words, the company's sales are declining because there are fewer and fewer individuals or companies on the market who would be willing to buy the product.

Consequently, the company's profits are also declining. The recessionary situation requires the company to reduce or no longer hire new workers. When redundancies become commonplace, productivity per worker will increase. The work process becomes more demanding and more prolonged, while the motivation and morale of the workers decline. To reduce operating costs, the company will start using cheaper raw materials and supplies, which may jeopardize the quality of products and services. Lack of financial resources leads to a reduction or even cessation of investment in improvements to existing and developing new products, equipment, and processes. The company spends less money on advertising and marketing. Suppliers are also at risk from restrictive cost-cutting measures because they face late payments. The company also starts paying its bills irregularly, with delays because it is facing liquidity problems. A company that is not creditworthy or has a bad rating is forced into reorganization or even liquidation.

\section{Methodology, data collection, and sample}

A quantitative survey was designed and conducted based on primary data collected through a structured questionnaire. The survey was conducted by distributing questionnaires via e-mail. The distribution of the questionnaires was initiated according to the snowball principle in all Slovenian regions. The target population of the survey was the population of Slovenian citizens between 18 and 65 years of age. We analysed the data by the corresponding statistical data processing methods in the SPSS statistical package.

The questionnaire included 18 questions, with the questions divided into three sets. The first set (1-6) - Buying behaviour, relate to comparing their behaviour before the epidemic with behaviour during the epidemic. In the second set (7-11) - Trust, Responsibility, and Flexibility, we were interested in how restrictive measures affected their buying habits and how quickly they adapted to the new situation. And the last, demographic set (12-18), we were interested in the following data: region of residence, age of respondents, gender, and level of education. None of the questions was open-ended. We used either pre-answered questions from which respondents could choose the appropriate option (especially in the demographic section) or a Likert 5-point rating scale, which was used to agree with specific answers and where participants could choose the appropriate level of agreement.

\section{Results and discussion}

203 participants participated in the survey, and 149 respondents completed it. For further data processing, only fully completed questionnaires were taken into account. 102 females completed the survey (68.4\%) and 47 males (31.6\%), shown in Figure 1. 


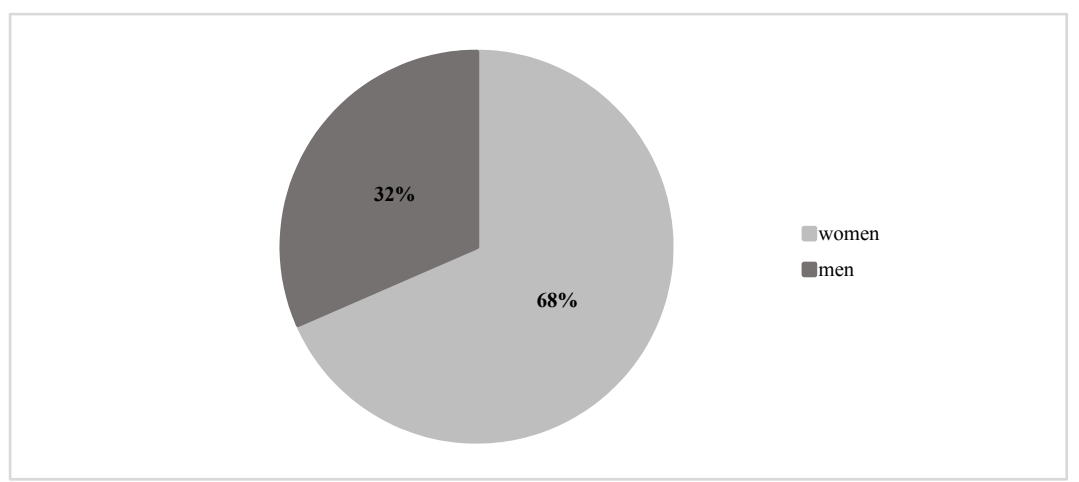

Figure 1: Gender of respondents

The age structure of the sample included respondents between 18 and 65 years of age. The average age of the respondents was 31.38 years, with $126(84.5 \%)$ respondents aged between 18 and 30 years included in the sample.

According to the analysis of the educational structure, the majority of respondents had completed secondary school, namely, 97 (65.1\%), followed by respondents with completed college or higher education, $34(22.8 \%)$, and those with a university degree or a completed Bologna master's degree, $12(8.0 \%)$, which represents a total of $96 \%$ of the sample. The rest is represented by $3(2.0 \%)$ respondents with a completed scientific master's degree or a doctorate, $2(1.3 \%)$ respondents with completed primary school, and $1(0.7 \%)$ respondent who have not even completed primary school.

The survey aimed to obtain data on the frequency of everyday products purchase before and during the epidemic. Figure 2 shows the differences in the purchase frequency for everyday products before the epidemic and during the Covid-19 epidemic. Given the situation, the frequency of purchases was expected to decrease. Before the epidemic, most respondents made purchases several times a week (44\%), while during the pandemic, most purchases were made once a week (61,3\%). During the state of the pandemic, shopping decreased several times a week (4,9\%), while shopping increased once a week $(61,3 \%)$.

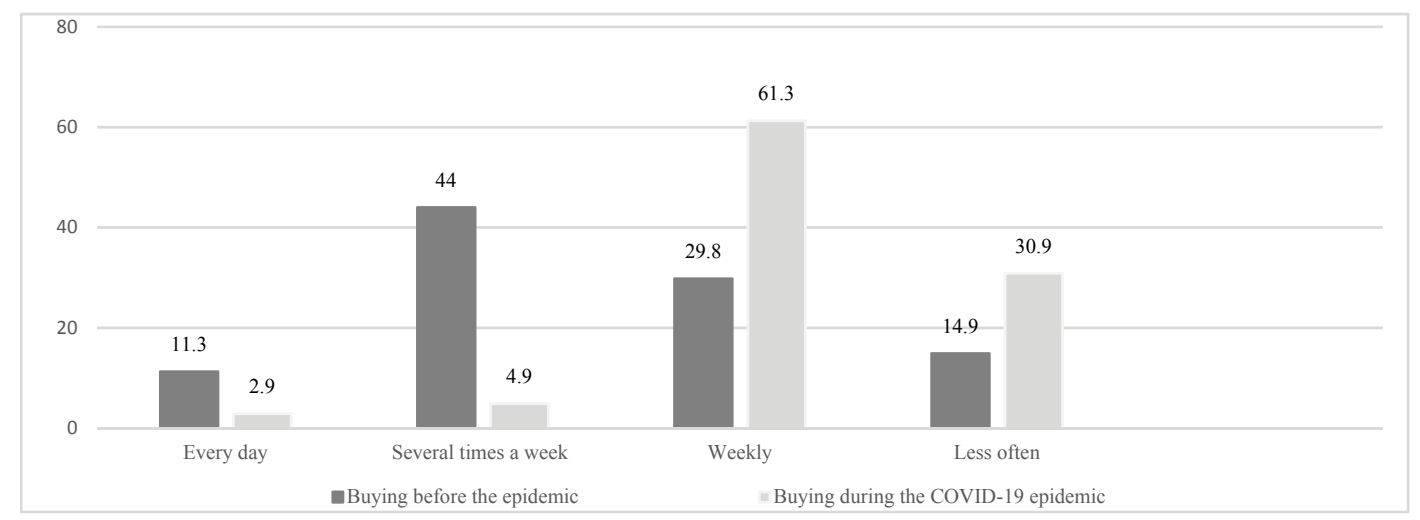

Figure 2: Comparison of purchase frequency for everyday products before and during the epidemic (\%)

During the epidemic, the number of those purchasing everyday products in several different stores decreased from 3.3 before the outbreak to 2.4 during the epidemic (Table 1). During the epidemic, the number of those who purchased everyday products online increased, from 2.4 before the outbreak to 2.9 during the epidemic. The frequency of following advertising leaflets 
and other electronic notifications of trade companies and responding to sales campaigns for everyday products decreased during the epidemic, namely from 2.6 before the outbreak to 2.5 during the epidemic. Purchasing everyday products did not represent a social event for respondents either before or during the epidemic. However, the number of those who bought everyday products spontaneously and according to their needs increased, from 3.2 before the outbreak to 3.8 during the epidemic.

Table 1: Comparison of buying behaviour for everyday products before and during the validity of measures to prevent the spread of Covid-19

\begin{tabular}{|l|l|l|}
\hline $\begin{array}{l}\text { Buying behaviour in everyday products before and during the validity of } \\
\text { measures to prevent the spread of Covid-19 }\end{array}$ & $\begin{array}{l}\text { Before the } \\
\text { adoption } \\
\text { measures (AV) } \\
\text { of })\end{array}$ & $\begin{array}{l}\text { During the period } \\
\text { of validity of the } \\
\text { measures (AV) }\end{array}$ \\
\hline I buy everyday products for the home in several different stores & 3.3 & 2.4 \\
\hline I buy everyday products for home online & 2.4 & 2.9 \\
\hline $\begin{array}{l}\text { I follow advertising leaflets and other electronic notifications of trade } \\
\text { companies and respond to favourable sales campaigns for everyday products }\end{array}$ & 2.6 & 2.5 \\
\hline $\begin{array}{l}\text { Shopping for everyday products for the home represents an event of the day - } \\
\text { socialising }\end{array}$ & 1.9 & 1.9 \\
\hline $\begin{array}{l}\text { I buy everyday products and equipment for home exercise spontaneously, } \\
\text { according to my needs }\end{array}$ & 3.2 & 3.8 \\
\hline
\end{tabular}

The shopping basket during the emergency was no different than before the epidemic (3.67) and was in line with actual consumption (3.57) (Figure 3). The average value of 2.21 tells us that no products in the basket were specially purchased precisely because of the emergency. There is a possibility that a basket appeared with less fresh fruit and vegetables and more goods with a longer shelf life (2.76). Also, an average value of 2.74 tells us that some respondents initially purchased more significant quantities of goods for personal use.

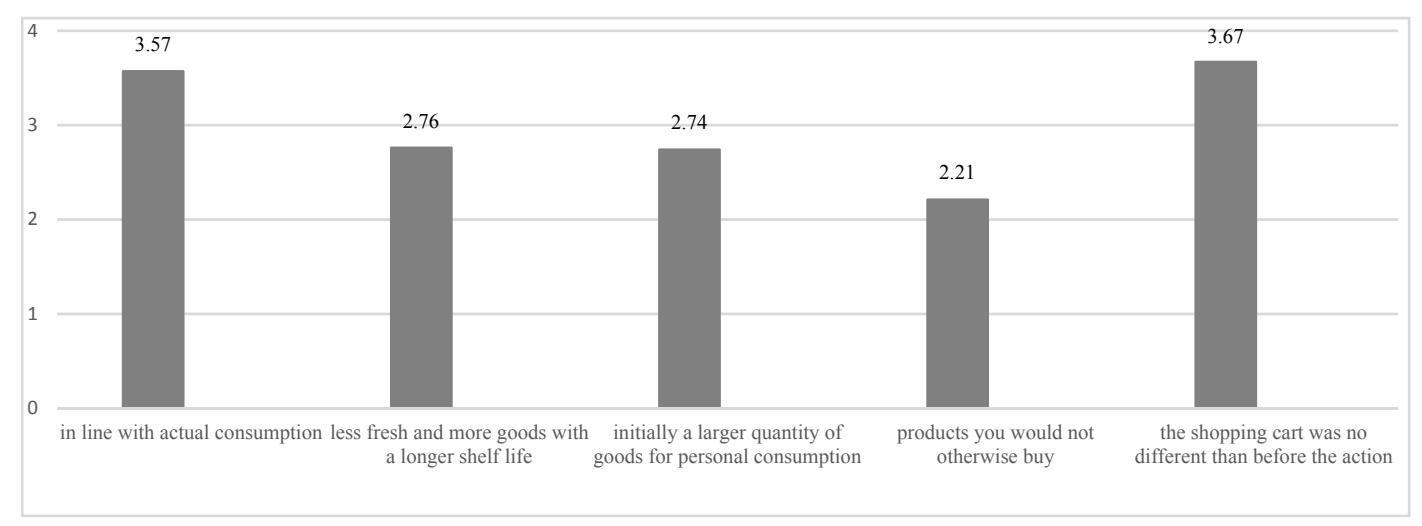

Figure 3: The average shopping cart during the epidemic

During the epidemic, some factors significantly impacted respondents' buying habits when buying everyday products. Respondents had to decide between very unfavourable (1) and very favourable (5). As evident from Table 2, buying habits were most negatively affected by restriction of movement to municipalities (average score 2.3), and similarly in a negative direction by lower incomes of respondents (average score 2.4). Based on the answers given by respondents, a more negligible negative impact was also observed concerning health care measures (average score 2.5). Meanwhile, identification of vulnerable groups, lack of social contacts, and opening hours of the stores had the most positive impact on the buying habits of the respondents (all with an average score of 2.8). The results, however, reflect a clear picture, as limiting factors harmed elements with an existing restriction in movement and financial capacity. In contrast, respondents who lacked social contacts did not care for vulnerable groups (confinement to the domestic environment). The adjusted opening hours of shops made them opt for sports activities more often. 
Table 2: Factors influencing respondents' buying habits when buying everyday products

\begin{tabular}{|l|l|}
\hline Pull factors of purchase & Average score (AV) \\
\hline Restriction to municipalities & 2.3 \\
\hline Lower revenue & 2.4 \\
\hline Health care measures & 2.5 \\
\hline Stress while organising a purchase & 2.6 \\
\hline Fear of infection & 2.6 \\
\hline Opening hours & 2.8 \\
\hline Lack of social contacts & 2.8 \\
\hline Identification of vulnerable groups & 2.8 \\
\hline
\end{tabular}

The following table presents the buying behaviour that respondents would retain after lifting the measures. Averages of responses are collected. The buying behaviour that respondents would most easily maintain is making more rational purchases and paying with a payment card. The lowest average of answers to this question was received using the online store to purchase everyday products, which means that this buying behaviour has become the least common for consumers.

Table 3: Buying behaviours that respondents would maintain after the time the measures were lifted

\begin{tabular}{|l|l|}
\hline Buying behaviour & Average score (AV) \\
\hline The tendency to make more rational purchases & 3.61 \\
\hline I will use a payment card for payment & 3.58 \\
\hline I won't be shopping on Sundays & 3.36 \\
\hline I will make purchases for a longer period (at least once a week) & 3.45 \\
\hline I will use the online store for my purchase of everyday products. & 3.21 \\
\hline
\end{tabular}

The epidemic triggered a change in buying habits that had to become more rational due to introduced measures. The definition of the buying habits of the respondents is presented in Figure 4. More than half of the respondents know that the measures are helpful, but they do not want to give up certain buying habits. $36 \%$ of respondents believe that measures are urgently needed and will therefore do their best to adhere to them, even if they suffer from a shortage. Few people feel that the measures are too grossly interfering with their buying habits which they will be maintaining at all costs.

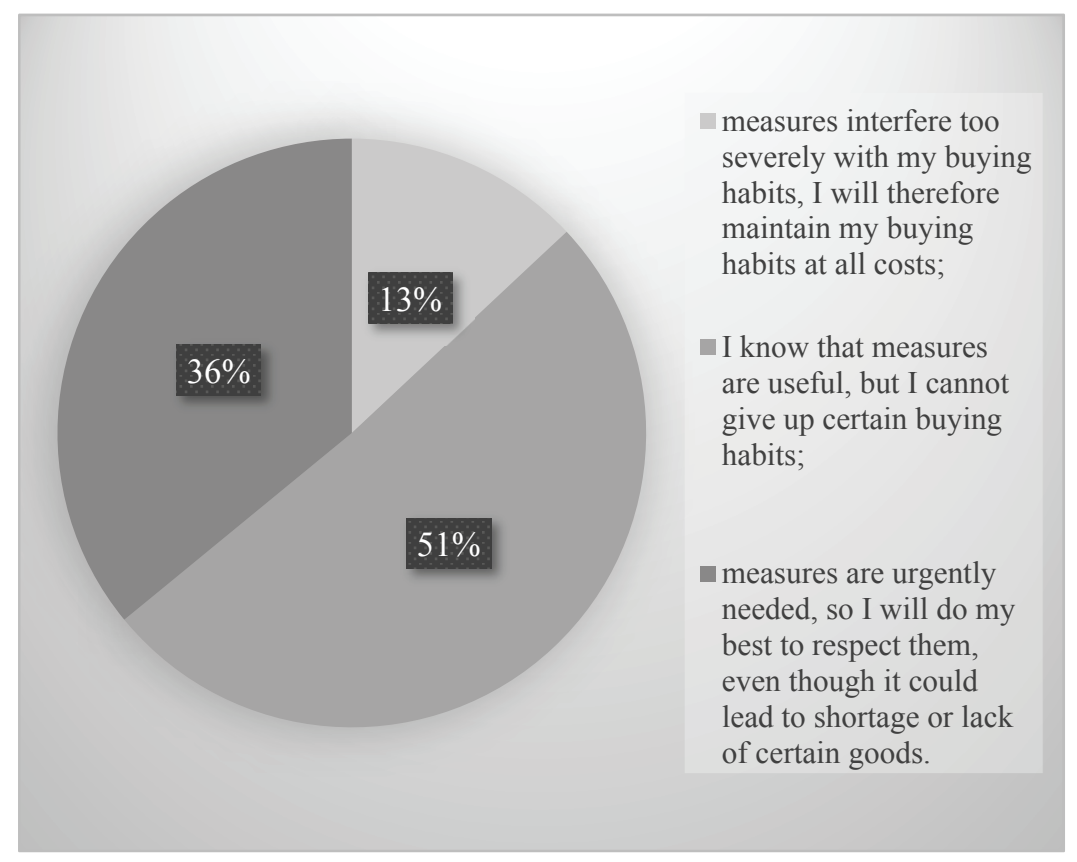

Figure 4: Definition of measures regarding the buying habits of the respondents

Consumers had to adjust their pre-epidemic buying habits at various speeds. Figure 5 shows how quickly respondents responded to the measures and became more rational and efficient in 
their shopping. As many as $57 \%$ of respondents believe that mass buying did not get them off track and that they organised and rationalised their purchases by adapting them. Almost a third of the respondents changed their buying habits when the measures were adopted, adjusted, and rationalised. Only $16 \%$ of people rationalised their purchases only after the end of mass buying. Slovenians are personally and socially responsible against the epidemics.

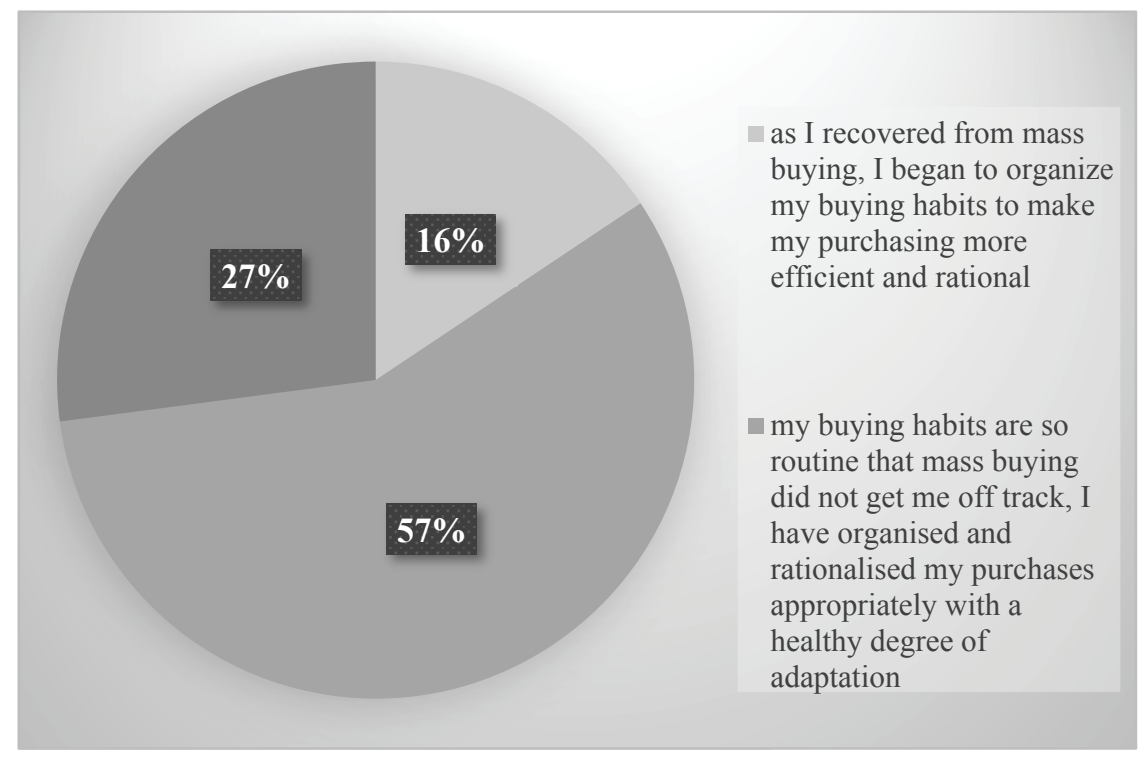

Figure 5: Pace of adjustment of buying habits

\section{Conclusion}

The market is changing rapidly and dynamically, and the battle for consumers between retailers is increasing. Retailers are constantly striving to offer something more than their competitors. There are always new ways to entice consumers to buy, either with a bargain or a good buying experience.

The coronavirus has significantly changed our lives this year. Quarantine and health measures have revolutionised the sale of food and necessities, making purchases unfamiliar. Both sellers and users of their goods and services have had to adapt to the unusual circumstances. In many elements, the epidemic has left negative consequences and caused many changes in consumer buying behaviour. During the epidemic, online sales increased significantly, providing suitable conditions for contactless businesses and access to desired consumer products. Therefore, its development will be even more urgent in the future and will coincide with the changing living environment and limiting factors. The main contribution to the research is represented by empirical analysis intended to reveal the possibility of theoretical and empirical findings to be put into practice, namely in the FMCG industry. In terms of its design and content, the study will represent one of the references in the field of marketing research and its narrower segment, consumer behaviour.

Changes are a constant, and we have noticed an unusually large number of them lately. The Covid-19 pandemic brings an uncertain future for the entire world. We will feel the negative consequences of implementing measures to curb the spread of the virus for a very long time to come. At the same time, we must not forget that a new factor may emerge on the path to rescuing from the crisis, which will make us wonder again how to proceed. Too much pessimism is dangerous, exaggerating with pessimistic predictions for the future can cause panic, too much optimism is inappropriate, even worse is covering up the actual situation, denying the crisis, and "sweeping problems under the rug". In the time we are in, nothing is as it should be. The situation is chaotic; when we look back in the future, we will marvel at everything that has 
changed to the time before the pandemic. Every bad thing also has something good in it. The crisis is creating a new order and putting some things in more appropriate places.

Given that the development of new technologies already enables digital retail today, the question arises as to whether this advancement of online shopping will also attract the consumer in shopping for food and everyday necessities? Perhaps it is because of the pandemic that we will witness the evolution of consumer buying behaviour. The consumer's need is to make an easy and quick purchase as much as possible. The complexity of online sales channels allows consumers to selectively search for important information or shortcuts when making purchasing decisions. Still, we must ask ourselves whether buying online really allows the consumer a sufficiently pleasant shopping experience.

\section{References}

Bennett, Jeff, (2011). The international handbook on non-market environmental valuation. Cheltenham in Northampton: Edward Elgar Publishing.

Blackwell, Roger D., Paul W. Miniard in James F. Engel. (2006). Consumer Behavior. 10th ed. Forth Worth: Dryden Press in London: Harcourt College Publishers.

del Rio-Chanona, R. M., Mealy, P., Pichler, A., Lafond, F. \& Farmer, D. (2020). Supply and demand shocks in the COVID-19 pandemic: an industry and occupation perspective. Oxford Review of Economic Policy, 36(S1), S94-S137.

Kotler, Philip in Gary Armstrong. (2018). Principles of Marketing. 17th ed. Harlow: Pearson Education Limited.

Kraus, S., Caluss, T., Breier, M., Gast, J., Zardini, A. \& Tiberius, V. (2020). The economics of COVID-19: initial empirical evidence on how family firms in five European countries cope with the corona crisis. International Journal of Entrepreneurial Behavior \& Research, 26(5), 1067-1092.

Peter, J. Paul in Jerry C. Olson. (2005). Consumer behavior and marketing strategy. 7th ed. New Delhi: McGrawHill.

Schiffman, Leon G. in Leslie Lazar Kanuk. (2015). Consumer behavior. Harlow: Pearson Education Limited.

Solomon, Michael R., Gary Bamossy, Søren Askegaard in Margaret K. Hogg. (2006). Consumer behaviour: A European perspective. 3rd ed. Harlow: Pearson Education.

Svetin, I. (2020). Kaj se je v Sloveniji spremenilo v zadnjem času? Statistični urad Republike Slovenije. Retrieved 10.3.2021 from https://www.stat.si/StatWeb/News/Index/8871.

Vukasović, T. (2020). Koncepti sodobnega trženja. Pearson Education Limited.

Vukasović, T. and Jagodič, G. (2021). Analysis of consumer buying behaviour when buying sports and leisure products during the COVID-19 pandemic. Monograph Chapter In Press In Impacts and Implications for the Sports Industry in the Post-COVID-19 Era. IGI Global Publisher of Timely Knowledge, 73-90.

Wang, Yonggui, Hing-Po Lo in Yongheng Yang. (2004). An integrated framework for service quality, customer value, satisfaction: Evidence from China's telecommunication industry. Information Systems Frontiers, 6 (4), 325-340.

WHO. (2020). Novel coronavirus (2019-nCoV) SITUATION REPORT - 1, Nover Coronavirus: World Health Organisation. Geneva, Health Organization. https://apps.who.int/iris/bitstream/handle/10665/330760/nCoVsitrep21Jan2020eng.pdf? sequence $=3 \&$ is Allowed $=y$ 